\section{Characterization of Hepatic Low Density Lipoprotein Binding and Cholesterol Metabolism in Normal and Homozygous Familial Hypercholesterolemic Subjects}

\author{
Jeffrey M. Hoeg, Stephen J. Demosky, Jr., \\ Ernst J. Schaefer, Thomas E. Starzl, \\ and H. Bryan Brewer, Jr. \\ Molecular Disease Branch, National Heart, Lung, and Blood \\ Institute, National Institutes of Health, Bethesda, Maryland \\ 20205; The University of Pittsburgh School of Medicine, \\ Pittsburgh, Pennsylvania 15260
}

A poproteins (LDL), increased hepatic synthesis of apolipoprotein B-containing lipoproteins, defective binding of low density lipoproteins to fibroblasts, and premature atherosclerosis. The role of a hepatic low density lipoprotein receptor in normal man and its importance in the pathogenesis of familial hypercholesterolemia have not been previously determined. In the present study, direct comparison was made of the binding of LDL to hepatic membranes from normal and receptor-negative homozygous familial hypercholesterolemic subjects. The effects of calcium, EDTA, and temperature on the binding of lipoproteins to the hepatic membranes were also evaluated. At $4^{\circ} \mathrm{C}$, no significant difference in specific binding of LDL to hepatic membranes from normal and familial hypercholesterolemic subjects was observed. At $37^{\circ} \mathrm{C}$, both total and specific binding of LDL were significantly reduced in patients with familial hypercholesterolemia. Hepatic membrane binding of LDL from the two patients homozygous for receptor-negative familial hypercholesterolemia was 53 and $59 \%$ of normal. The activity of the rate-limiting enzyme in cholesterol biosynthesis, 3-hydroxy-3-methylglutaryl coenzyme A reductase was normal; however, the total hepatic cholesterol and cholesteryl ester content was significantly increased from 53 to $129 \%$.

A preliminary account of this work was presented at the American Federation for Clinical Research Meetings held in Washington DC, May 1982.

Received for publication 9 September 1982 and in revised form 4 August 1983.

The Journal of Clinical Investigation, Inc.

Volume 73, February 1984, 429-436
These results indicate that patients with familial hypercholesterolemia have a defect in the interaction of hepatic membranes with low density lipoproteins. This defect may lead to accelerated atherosclerosis by decreasing the cellular catabolism of LDL and enhancing the production of LDL, which is characteristic of patients homozygous for familial hypercholesterolemia.

\section{Introduction}

Familial hypercholesterolemia (FH) ${ }^{1}$ is an autosomal co-dominant disorder characterized clinically by hypercholesterolemia, xanthomas, and premature atherosclerosis (1). In vitro study of skin fibroblasts from patients homozygous for FH revealed that the disorder is caused by one of several mutations in the gene coding for the cellular receptor for low density lipoproteins (LDL) $(2,3)$. This LDL receptor normally binds LDL, which is then internalized and degraded in the lysosomes, and provides cholesterol for use in cellular metabolism (4). Fibroblasts from patients homozygous for $\mathrm{FH}$ who have the most frequent allelic mutation have no functional receptors and are referred to as receptor-negative (3). Therefore, it is thought that when the receptor is functionally absent, $L D L$ is not degraded at a normal rate and plasma LDL concentration increases.

The liver plays a central role in cholesterol and lipoprotein metabolism (5-7). Endogenous cholesterol synthesis occurs in the liver and the precursor to plasma LDL, very low density lipoproteins (VLDL), are synthesized and secreted by the liver $(5,8)$. Moreover, recent studies, in rats, mice, dogs, and rabbits have demonstrated specific binding of LDL to the liver (9-13). The physiologic role of such LDL-hepatic interaction in man and the pathophysiologic significance of LDL-hepatic interaction

1. Abbreviations used in this paper: $\mathrm{FH}$, familial hypercholesterolemia; HMG-CoA, 3-hydroxy-3-methylglutaryl coenzyme A reductase; LPDS, lipoprotein-deficient serum; TrisCl, Tris (hydroxymethyl) aminomethane. 
in FH has been previously unknown. The current studies were designed to quantitate hepatic LDL membrane binding, cholesterol/cholesteryl ester content, and 3-hydroxy-3-methylglutaryl coenzyme A (HMG-CoA) reductase activity in normal subjects and $\mathrm{FH}$ patients.

\section{Methods}

Patients. Subjects from two unrelated kindreds were evaluated by physicians of the Molecular Disease Branch of the National Heart, Lung, and Blood Institute at the Clinical Center of the National Institutes of Health in Bethesda, MD. The clinical data from these patients are summarized in Table I. The clinical diagnosis of FH was based on the presence of hypercholesterolemia, tendon xanthomas, premature atherosclerosis, plasma LDL cholesterol in excess of two standard deviations of the mean normal levels for age and sex, and an inheritance pattern consistent with the diagnosis (1). Skin biopsies for fibroblast studies were obtained from normolipidemic volunteers and the two patients homozygous for this disease (D.P., T.H.). Liver biopsies were performed on normolipidemic renal transplant donors (ages 21, 27, 32, and $36 \mathrm{yr}$ ) and from D.P. and T.H. at the time of portacaval shunt of the liver for treatment of these patients' conditions after obtaining informed consent. The liver biopsy protocol was approved by the Human Experimentations Committee at the University of Pittsburgh, where the biopsies were performed.

Lipoprotein isolation. Human LDL $(d 1.030-1.050 \mathrm{~g} / \mathrm{ml})$ and lipoprotein-deficient serum $(d<1.215 \mathrm{~g} / \mathrm{ml})$ were prepared from $500 \mathrm{ml}$ plasma collected in $0.01 \%$ EDTA by plasmapheresis from fasting, healthy volunteers. Lipoproteins were separated by preparative ultracentrifugation at $4^{\circ} \mathrm{C}$ for $16-24 \mathrm{~h}$ (14) using $\mathrm{KBr}$ for density-gradient adjustment (15). These subfractions were then dialyzed $34 \mathrm{~h}$ at $4^{\circ} \mathrm{C}$ against $150 \mathrm{vol}$ of phosphate-buffered saline (PBS) (pH 7.0) (Gibco Laboratories, Grand Island, NY). After dialysis, lipoprotein-deficient serum (LPDS) was defibrinated with thrombin (Park, Davis and Co., Detroit, MI). Each isolated lipoprotein fraction was sterilized by $0.45-\mu \mathrm{m}$ Millipore filtration (Millipore Corp., Bedford, MA) and used within 1 mo of preparation. ${ }^{125}$ ILDL was prepared by the iodine monochloride method (16) as modified for lipoproteins (17). A $25-30 \%$ efficiency of iodination was obtained and $<6 \%$ of the radioactivity was soluble in the organic phase following a chloroform-methanol extraction. After dialysis over $24 \mathrm{~h}$ at $4^{\circ} \mathrm{C}$ against 500-600 vol PBS, specific activities ranged from 2.7 to $4.6 \times 10^{9} \mathrm{Bec}-$ querels/mg LDL protein. The concentration of LDL is expressed in terms of its protein content using bovine serum albumin standard as determined by the method of Lowry et al. (18). After Millipore filtration, ${ }^{125} \mathrm{I}-\mathrm{LDL}$ was stored at $4^{\circ} \mathrm{C}$ and used within 2-3 wk of preparation. LDL used for competition assays was modified by acetoacetylation as described by Mahley et al. (19).

Fibroblast preparation. The fibroblasts used in these studies were established from explants of skin obtained from the study subjects by punch biopsy. All cell lines were grown in monolayer and used after three to seven passages. Cell lines were maintained in a humidified incubator at $37^{\circ} \mathrm{C}$ in a $5 \% \mathrm{CO}_{2}$ atmosphere in $150-\mathrm{cm}^{2}$ sterile flasks (Costar, Cambridge, MA). Eagles minimal essential medium was supplemented by $2 \mathrm{mM}$ glutamine (Gibco Laboratories) and 10\% (vol/vol) fetal calf serum (Sterile Systems, Inc., Logan, UT). For the ${ }^{125}$ I-LDL experiments, $1 \times 10^{5}$ cells were harvested on day 0 with $0.05 \%$ trypsin$0.05 \%$ EDTA and placed in $30-\mathrm{mm}$ petri dishes (Costar). On days 1 , 3 , and 5 the media was replaced with fresh growth media supplemented with $10 \%$ (vol/vol) fetal calf serum. On day 6 , when cells were still preconfluent (4-6 $\times 10^{5}$ cells/plate), the media was replaced with $3 \mathrm{ml}$ of fresh media containing $10 \%$ (vol/vol) LPDS (final protein concentration, $2.5 \mathrm{mg} / \mathrm{ml}$ ). For the HMG-CoA reductase assays, $2 \times 10^{6}$ trypsinized fibroblasts were added to $10 \mathrm{ml}$ of media containing $10 \%$ (vol/ vol) LPDS in 100-mm petri dishes (Falcon Labware, Oxnard, CA). The $10 \%$ LPDS media was replaced $24 \mathrm{~h}$ after initial seeding. After $36 \mathrm{~h}$ of incubation in 10\% LPDS media, cells were prepared for assay of HMGCoA reductase activity.

Liver membrane preparation. Biopsy specimens were immediately placed in a beaker and all processing occurred at $4^{\circ} \mathrm{C}(20,21)$. After mincing the tissue with a razor blade, it was washed with an ice-cold buffer containing $0.9 \%$ (vol/vol) $\mathrm{NaCl}, 1 \mathrm{mM}$ EDTA, $10 \mathrm{mM}$ Tris (hydroxymethyl) aminomethane (TrisCl) (pH 8.0). Homogenization was performed by six strokes of a motor-driven Teflon pestle in a buffer containing $0.25 \mathrm{M}$ sucrose, $1 \mathrm{mM}$ EDTA, and $10 \mathrm{mM}$ TrisCl (pH 8.0). The homogenized preparations $(10 \mathrm{mg} / \mathrm{ml})$ were centrifuged for $10 \mathrm{~min}$ at $1,000 \mathrm{~g}$. The supernatant solution was recentrifuged for $25 \mathrm{~min}$ at $10,000 \mathrm{~g}$, followed by ultracentrifugation at $100,000 \mathrm{~g}$ for $60 \mathrm{~min}$. The pellet from this ultracentrifugation was resuspended in a buffer containing $150 \mathrm{mM} \mathrm{NaCl}, 10 \mathrm{mM} \mathrm{TrisCl}$ (pH 8.0), and flushed through a 22-gauge needle 10 times. These membranes were recentrifuged for $15 \mathrm{~min}$ at $100,000 \mathrm{~g}$ and the membrane pellets were then frozen in dry ice and stored in liquid nitrogen until they were used for binding assays and measurement of HMG-CoA reductase activity.

HMG-CoA reductase assay. Cells and hepatic membranes were prepared as described above and fibroblasts were incubated for $36 \mathrm{~h}$ in $10 \%$ LPDS. The media was then replaced by $10 \%$ LPDS containing one of the following concentrations of LDL protein: $5,15,25,50,75$, or 100 $\mu \mathrm{g} / \mathrm{ml}$. After $6 \mathrm{~h}$ of incubation with LDL, cells were washed four times with $2 \mathrm{ml}$ of ice-cold PBS (pH 7.0) and scraped with a rubber policeman. The contents of duplicate $100-\mathrm{mm}$ petri dishes were then pooled and centrifuged for $20 \mathrm{~min}$ at $4^{\circ} \mathrm{C}$. The supernatant was decanted and cell pellets frozen in dry ice. Cell pellets from both fibroblasts as well as liver membranes were then stored in liquid nitrogen until HMG-CoA reductase activity was quantitated. All assays were performed within 4 d of cell harvesting and repetitive studies indicated no loss of HMGCoA reductase activity over this time period. The HMG-CoA reductase assay used was modified from that described by Beg et al. (22). Cell pellets were thawed slowly to room temperature and then subjected to membrane dissolution with $200 \mu \mathrm{l} 0.1 \mathrm{M} \mathrm{KH}_{2} \mathrm{PO}_{4}, 1 \mathrm{mM}$ EDTA, 10 $\mathrm{mM} \mathrm{KCl}$, and $4 \mathrm{mM}$ 3-[(3-cholamidopropyl)dimethyl-ammonio]-1propane-sulfonate- $2 \mathrm{H}_{2} \mathrm{O}$ (Calbiochem-Behring Corp., La Jolla, CA.) at pH 7.5. After a 10 -min, $4^{\circ} \mathrm{C}$ incubation, $45 \mu \mathrm{l}$ of this fractionated cell suspension was added to $125 \mu \mathrm{l}$ of substrate buffer $\left(0.16 \mathrm{M} \mathrm{KH}_{2} \mathrm{PO}_{4}\right.$, $67 \mathrm{mM}$ EDTA, $5 \mathrm{mM}$ dithiothreitol, and $10 \mathrm{mM}$ NADPH, at pH 7.0). $\left[{ }^{3} \mathrm{H}\right]$ Mevalonic acid (New England Nuclear, Boston, MA) was added to each sample for internal standardization. Unlabeled HMG-CoA was added to $d, l-\left[3-{ }^{14} \mathrm{C}\right] \mathrm{HMG}-\mathrm{CoA}$ (New England Nuclear) to produce a final specific activity of $4.92 \times 10^{8}$ Bequerels $(\mathrm{dps}) / \mathrm{mM}$. The final assay volume was adjusted to $200 \mu \mathrm{l}$ by the addition of $30 \mu \mathrm{l}$ of $d, l-\left[3-{ }^{14} \mathrm{C}\right]-$ HMG-CoA. Incubation was carried out for $30 \mathrm{~min}$ in a $37^{\circ} \mathrm{C}$ shaker bath. The reaction was terminated by the addition of $40 \mu l$ of $10 \mathrm{~N} \mathrm{HCl}$ followed by a 1-min centrifugation in a microfuge B (Beckman Instruments, Inc., Palo Alto, CA). The final labeled product, $\left[{ }^{14} \mathrm{C}\right]$ mevalonic acid, was isolated by applying $120 \mu \mathrm{l}$ of the incubation supernatant to a $1 \mathrm{ml}$ Bio-Rex 5, 100-200 mesh anion-exchange column (Bio-Rad Laboratories, Richmond, CA). The isolated $\left[{ }^{14} \mathrm{C}\right]$ mevalonate was quantified in a liquid scintillation system Mark III (Searle Analytic, Inc., Skokie, IL). The quantity of protein in each incubation was determined by the method of Lowry et al. (18) and HMG-CoA reductase activity 
was expressed as disintegrations per minute per milligram of protein. The amount of protein per sample ranged from 100 to $200 \mu \mathrm{g}$ and all assays were performed in the linear range.

Binding of ${ }^{125}$ I-LDL to liver membranes. The frozen liver membrane preparations were thawed and resuspended through a 22-gauge needle in a $50 \mathrm{mM} \mathrm{NaCl}, 30 \mathrm{mM}$ TrisCl ( $\mathrm{pH} 7.5$ ) buffer to a membrane protein concentration of $10-12 \mathrm{mg} / \mathrm{ml}$. Membranes were then sonicated by five 4-s pulses at the 55-W setting, using an Ultrasonics microtip (Heat Systems Ultrasonics, Inc., Plainview, NY). From 100 to $200 \mu \mathrm{g}$ membrane protein suspended in a buffer containing $75 \mathrm{mM} \mathrm{NaCl}, 150 \mathrm{mM}$ TrisCl (pH 7.5) was then added to a $50 \mathrm{mM} \mathrm{NaCl}, 20 \mathrm{mM}$ TrisCl (pH 7.5) buffer containing either $1 \mathrm{mM} \mathrm{CaCl}{ }_{2}$ or $30 \mathrm{mM}$ EDTA. ${ }^{125} \mathrm{I}-\mathrm{LDL}$ was added at the concentrations indicated in the respective Tables and Figure legends with or without unlabeled LDL to a total assay mixture volume of $0.1 \mathrm{ml}$. Incubations were carried out at $0^{\circ}$ or $37^{\circ} \mathrm{C}$ for $30 \mathrm{~min}$. Bound ${ }^{125} \mathrm{I}-\mathrm{LDL}$ was separated from free ligand by a 3-min, $100,000 \mathrm{~g}$ centrifugation of $50 \mu \mathrm{l}$ of the assay mixture through $125 \mu \mathrm{l}$ PBS in a $30^{\circ}$ angle rotor in an air-driven ultracentrifuge (Beckman Instruments, Inc.). The supernatant was removed from the pellet by vacuum aspiration, and the pellet was washed once with $125 \mu \mathrm{l}$ of PBS. The cellulose nitrate tube tips containing the membrane pellet were sliced and the radioactivity in the pellet quantified in a Biogamma II scintillation counter (Beckman Instruments, Inc.). Specifically bound ${ }^{125}$ I-LDL was defined as the difference in ${ }^{125} \mathrm{I}-\mathrm{LDL}$ quantitated in samples that were incubated with and without $3,900-4,600 \mu \mathrm{g} / \mathrm{ml}$ of unlabeled LDL. Competition binding experiments were conducted by assessing the specific ${ }^{125}$ I-LDL binding in the presence of the indicated concentrations of unlabeled LDL, acetoacetylated LDL, or asialofetuin.

Lipoprotein quantitation. Blood was obtained in 0.1\% EDTA from subjects after a 12 - to 14 -h overnight fast, and the plasma was separated at $4^{\circ} \mathrm{C}$ in a refrigerated centrifuge. Plasma cholesterol and triglycerides were quantitated with an Autoanalyzer II (Technicon Instruments Corp., Tarrytown, NY) (23). High density lipoprotein (HDL) cholesterol was measured after heparin manganese precipitation in plasma (24). Plasma was ultracentrifuged at $d<1.006 \mathrm{~g} / \mathrm{ml}$ for $18 \mathrm{~h}$ at $39,000 \mathrm{rpm}\left(4^{\circ} \mathrm{C}\right)$ in 40.3 rotors (Beckman Instruments, Inc.), and the VLDL was separated from the other plasma lipoproteins by tube slicing (14). The cholesterol concentration in the $1.006 \mathrm{~g} / \mathrm{ml}$ infranate was measured, and the VLDL and LDL cholesterol were calculated (22).

Hepatic cholesterol and cholesteryl ester determination. Liver biopsy samples from three normal subjects, patient D.P., and patient T.H. were weighed, extracted three times with chloroform/methanol (2:1 vol/vol; $60-240 \mathrm{mg} / \mathrm{ml}$ ) at $41^{\circ} \mathrm{C}$. This extraction was followed by an overnight extraction with chloroform/methanol $(2: 1, \mathrm{vol} / \mathrm{vol})$ at $30^{\circ} \mathrm{C}$. The chloroform/methanol was blown to dryness and the liquid was resuspended in 2-propanol (J. T. Baker Chemical Co., Phillipsburg, NJ). Free and total cholesterol were then measured by the enzymic, fluorimetric method of Heider and Boyette (25). Esterified cholesterol was determined as the difference between total and free cholesterol. The nanomoles of cholesterol extracted from the biopsy samples were then normalized to the initial sample weight.

\section{Results}

Patient clinical data. The clinical data of the patients from the two kindreds that were evaluated are summarized in Table I. These data were consistent with the clinical diagnosis of FH. Despite the use of a hypocholesterolemic diet and a variety of drugs, the levels of total plasma cholesterol and LDL cholesterol

Table I. Summary of Clinical Data

\begin{tabular}{|c|c|c|c|c|c|c|c|c|c|c|c|}
\hline \multirow[b]{2}{*}{ Subject } & \multirow[b]{2}{*}{ Position } & \multirow[b]{2}{*}{ Age } & \multirow[b]{2}{*}{ Sex } & \multicolumn{4}{|c|}{ Plasma cholesterol } & \multirow{2}{*}{$\begin{array}{l}\text { Plasma } \\
\text { triglycerides }\end{array}$} & \multirow{2}{*}{$\begin{array}{l}\text { Lipid lowering } \\
\text { treatment }\end{array}$} & \multirow[b]{2}{*}{ Disease } & \multirow[b]{2}{*}{ Diagnosis } \\
\hline & & & & Total & LDL & VLDL & HDL & & & & \\
\hline & & & & & & & & $m g / d l$ & & & \\
\hline \multicolumn{12}{|c|}{ Kindred 1} \\
\hline H.P. & Father & 37 & $\mathbf{M}$ & 348 & 284 & 42 & 23 & 345 & $\begin{array}{l}\text { Niacin neomycin } \\
\text { colestipol }\end{array}$ & $\begin{array}{l}\text { Angina } \\
\text { CABG* }\end{array}$ & FH heterozygote \\
\hline S.P. & Mother & 35 & $\mathrm{~F}$ & 353 & 263 & 54 & 36 & 218 & Colestipol & Carotid Bruit & FH heterozygote \\
\hline D.P. & Son & 7 & $\mathbf{M}$ & 849 & 810 & 37 & 2 & 258 & Neomycin & $\begin{array}{l}\text { Bilateral } \\
\text { Femoral } \\
\text { Bruits }\end{array}$ & FH homozygote \\
\hline M.P. & Daughter & 8 & $\mathbf{F}$ & 362 & 288 & 34 & 40 & 88 & Diet & $\begin{array}{l}\text { None } \\
\text { Evident }\end{array}$ & FH heterozygote \\
\hline \multicolumn{12}{|c|}{ Kindred 2} \\
\hline B.H. & Mother & 42 & $\mathrm{~F}$ & 462 & 359 & 82 & 21 & 414 & Clofibrate & $\begin{array}{c}\text { MI‡, CABG* } \\
\text { Deceased }\end{array}$ & FH heterozygote \\
\hline T.H. & Daughter & 21 & $\mathrm{~F}$ & 908 & 843 & 52 & 13 & 222 & $\begin{array}{l}\text { Niacin } \\
\text { cholestyramine }\end{array}$ & $\begin{array}{l}\text { Angina MI } \\
\text { CABG }^{*}\end{array}$ & FH homozygote \\
\hline
\end{tabular}

* CABG, coronary artery bypass graft. $¥$ MI, documented myocardial infarction. 
were strikingly elevated in heterozygotes as well as homozygotes. Total plasma cholesterol for heterozygotes ranged from 348 to $462 \mathrm{mg} / \mathrm{dl}$ and homozygotes had approximately double these values at 849 and 908 , despite therapeutic trials of a variety of agents.

Fibroblast HMG-CoA reductase activity. The LDL receptor status was determined by studies performed on fibroblasts from these two homozygous patients. First, the ability of LDL to suppress the activity of the rate-limiting enzyme for cellular cholesterol synthesis, HMG-CoA reductase, was assessed in normal fibroblasts and in fibroblasts from D.P. and T.H. (Fig. 1). As little as $10 \mu \mathrm{g} / \mathrm{ml}$ of LDL protein in the media suppressed the activity of HMG-CoA reductase by $>60 \%$ in normal fibroblasts. There was a progressive decrease in HMG-CoA reductase activity with increasing concentrations of LDL in the media in normal cells. In fibroblasts from D.P. and T.H., on the other hand, increasing concentrations of LDL had no effect on the activity of HMG-CoA reductase. Even $100 \mu \mathrm{g} / \mathrm{ml}$ of LDL protein did not reduce the activity of this enzyme below that seen in the cells grown in the absence of LDL in the media. In addition, using their immunoblotting technique, Beisiegel et al. (26) found no LDL receptors in fibroblasts from these patients. Thus, these two individuals have been designated as receptor-negative FH.

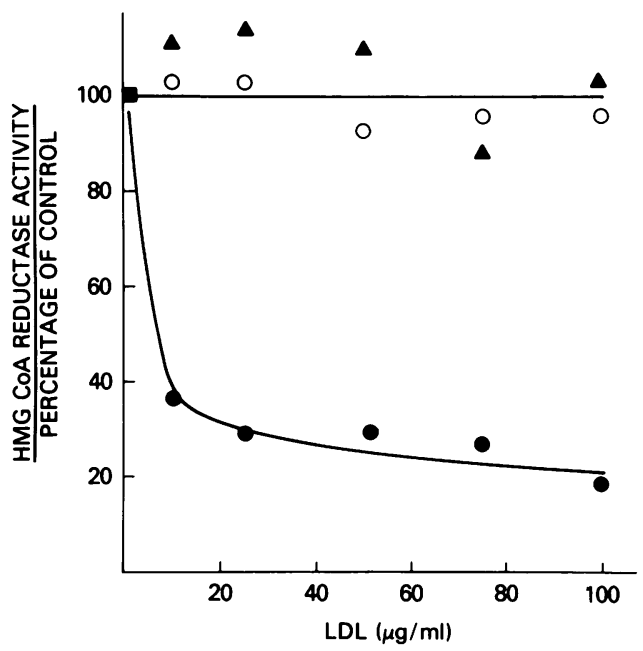

Figure 1. The effect of LDL on the HMG-CoA reductase activity of fibroblasts from normal and familial hypercholesterolemic subjects. Preconfluent fibroblasts from a normal subject (๑), T.H. (O), and D.P. ( $\triangle$ ) were incubated $36 \mathrm{~h}$ in 10\% LPDS media. Media was replaced with the indicated concentrations of LDL and the cells were then incubated for $6 \mathrm{~h}$ at $37^{\circ} \mathrm{C}$. After extensive washing, cells were harvested with a rubber policeman, pelleted, and frozen. After solubilization of the cells, the conversion of $\left[{ }^{14} \mathrm{C}\right] \mathrm{HMG}-\mathrm{CoA}$ to

$\left[{ }^{14} \mathrm{C}\right]$ mevalonate was measured after a $30 \mathrm{~min}, 37^{\circ} \mathrm{C}$ incubation and corrected for total cellular protein. The normal activity of fibroblasts not exposed to LDL, used as $100 \%$ activity, was $216 \mathrm{pmol} / \mathrm{mg}$ cellular protein. The activity of HMG-CoA reductase is expressed as the percentage of activity observed in the absence of LDL. Values represent the mean of duplicate plates.

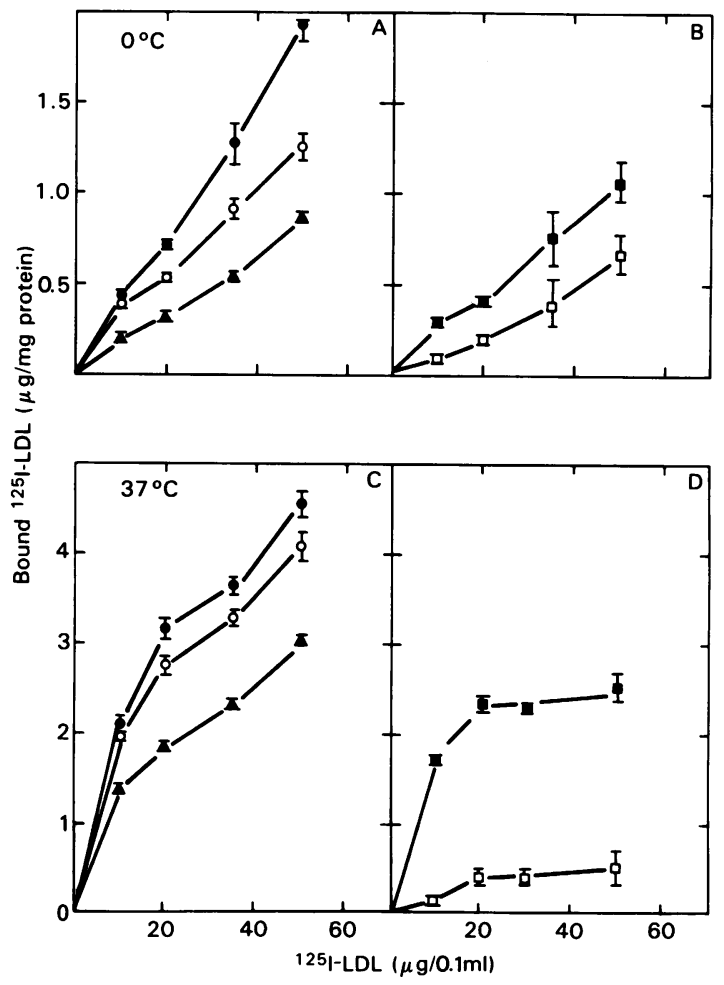

Figure 2. The effect of incubation temperature, calcium, EDTA, and excess unlabeled LDL on the binding of ${ }^{125}$ I-LDL to adult human hepatic membranes. From 138 to $182 \mu \mathrm{g}$ of hepatic membranes were added to a $75 \mathrm{mM} \mathrm{NaCl}, 150 \mathrm{mM}$ TrisCl buffer containing $1 \mathrm{mM}$ $\mathrm{CaCl}_{2}(\bullet), 30 \mathrm{mM}$ EDTA (0) or 20-fold excess unlabeled LDL (४). These mixtures were then incubated for $30 \mathrm{~min}$ at the indicated concentrations of ${ }^{125} \mathrm{I}-\mathrm{LDL}$ at either $0^{\circ} \mathrm{C}(A$ and $B)$ or $37^{\circ} \mathrm{C}(C$ and $D)$. Total specific binding ( $\square$ ) and EDTA sensitive binding ( $\square$ ) were the differences between the binding observed in the absence and presence of unlabeled LDL and between the binding observed in $1 \mathrm{mM} \mathrm{CaCl}$ and $30 \mathrm{mM}$ EDTA, respectively. Values represent the mean $\pm \mathrm{SE}$ of triplicate samples.

Binding of ${ }^{125} I-L D L$ to adult human hepatic membranes. The ability of hepatic membranes isolated from the study subjects to bind ${ }^{125} \mathrm{I}-\mathrm{LDL}$ was assessed. The effects of incubation temperature, calcium, and a 20 -fold excess of LDL on this ${ }^{125}$ ILDL-membrane interaction are summarized in Fig. 2. Total, EDTA resistant, and nonspecific ${ }^{125}$ I-LDL binding were all much lower during the $0^{\circ} \mathrm{C}$ incubation (Fig. $2 A$ ) than observed at $37^{\circ} \mathrm{C}$ (Fig. $2 \mathrm{C}$ ) with a two to fourfold increase in binding at the higher temperature. The specific ${ }^{125}$ I-LDL binding (Fig. 2 $B$ and $D$ ), defined as the difference in binding observed in the absence and presence of unlabeled LDL, was quantitatively as well as qualitatively different between membranes incubated at $0^{\circ}$ and $37^{\circ} \mathrm{C}$. Binding assays conducted at $37^{\circ} \mathrm{C}$ resulted in not only a two to fourfold increase in the specific binding occurring at $0^{\circ} \mathrm{C}$, but also the $37^{\circ} \mathrm{C}$ binding using a constant 20 -fold excess unlabeled LDL reached saturation while the $\mathrm{O}^{\circ} \mathrm{C}$ binding 
was nonsaturable. Therefore, incubation temperature markedly affected not only the degree of ${ }^{125} \mathrm{I}-\mathrm{LDL}$ binding, but also the saturation characteristics.

Incubation temperature and ${ }^{125} \mathrm{I}-\mathrm{LDL}$ concentration also affected the degree of EDTA resistant binding. At $0^{\circ} \mathrm{C}$ (Fig. 2 $B$ ), the calcium-dependent binding, defined as the difference in binding observed in the presence of $1 \mathrm{mM} \mathrm{CaCl}_{2}$ and $30 \mathrm{mM}$ EDTA, initially was $20 \%$ of the total specific LDL binding. At the $50-\mu \mathrm{g} /$ assay ${ }^{125} \mathrm{I}-\mathrm{LDL}$ concentration, however, calcium-dependent binding was more often $50 \%$ of the total specific binding. In contrast, the calcium-dependent binding at $37^{\circ} \mathrm{C}$ (Fig. $2 \mathrm{D}$ ) reflected about one-third of specific ${ }^{125}$ I-LDL binding regardless of concentration. Furthermore, the calcium-dependent binding at $37^{\circ} \mathrm{C}$ demonstrated saturability, whereas at $0^{\circ} \mathrm{C}$ there was no saturability at the concentrations tested. These observations indicate that the binding of ${ }^{125} \mathrm{I}-\mathrm{LDL}$ to human hepatic membranes is highly temperature dependent and that at physiologic temperature and LDL concentration binding is saturable and specific with both calcium-dependent as well as calcium-independent characteristics.

The specificity of LDL-membrane interaction observed at $37^{\circ} \mathrm{C}$ was assessed by competitive binding assays of LDL, acetoacetylated LDL, and asialofetuin with ${ }^{125}$ I-LDL (Fig. 3). As

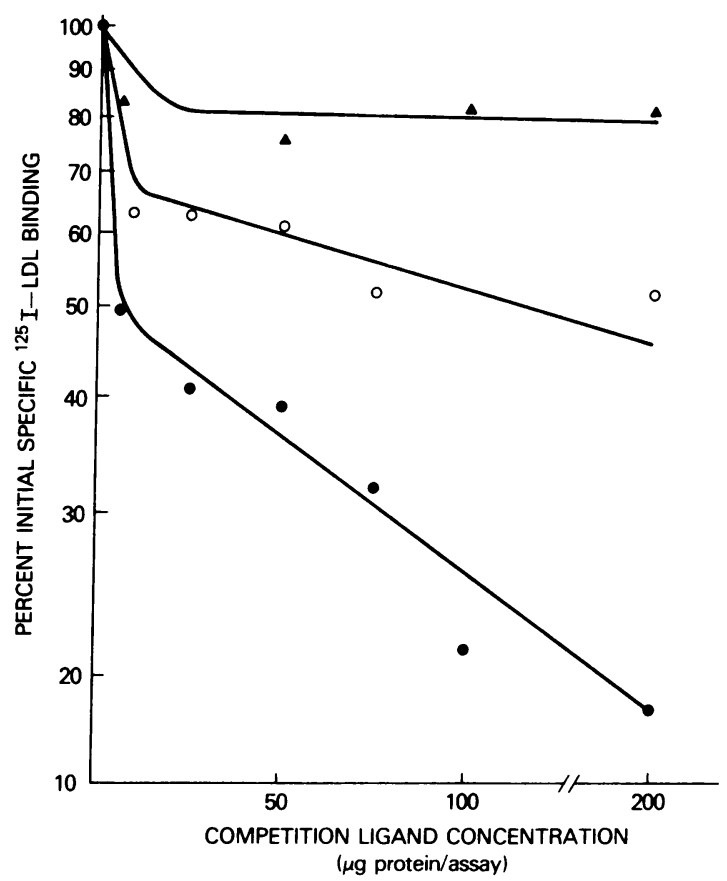

Figure 3. The competition for specific ${ }^{125}$ I-LDL binding with LDL, modified LDL, and asialofetuin. Increasing concentrations of LDL $(\bullet)$, acetoacetylated LDL (O), and asialofetuin ( $\Delta$ ) were incubated with 100-200 $\mu \mathrm{g}$ hepatic membrane protein and $20 \mu \mathrm{g}{ }^{125} \mathrm{I}-\mathrm{LDL}$ in the presence of $1 \mathrm{mM}$ calcium for $30 \mathrm{~min}$ at $37^{\circ} \mathrm{C}$. The $100 \%$ initial specific activity observed was $1.562 \mu \mathrm{g}{ }^{125} \mathrm{I}-\mathrm{LDL}$ bound/mg membrane protein.

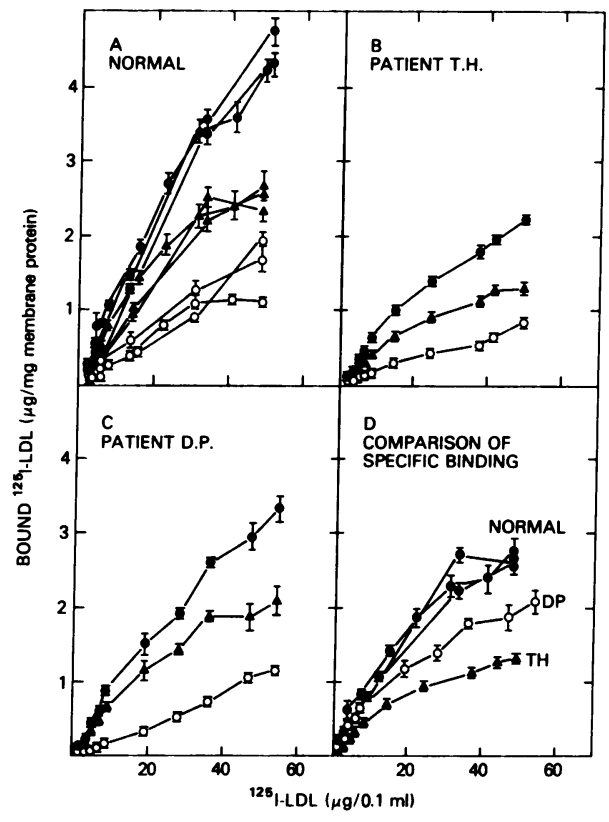

Figure 4. Binding of ${ }^{125}$ I-LDL to hepatic membranes from normal and familial hypercholesterolemic subjects. Membranes were prepared from hepatic biopsy specimens from three normal subjects $(A)$, T.H. (B), and D.P. $(C)$. From 100 to $200 \mu \mathrm{g}$ membrane protein was added to a $75 \mathrm{mM} \mathrm{NaCl}, 150 \mathrm{mM}$ TrisCl, $1 \mathrm{mM} \mathrm{CaCl}_{2}$ (pH 7.5) buffer with the indicated concentrations of ${ }^{125} \mathrm{I}-\mathrm{LDL}$ in the presence and absence of $396 \mu \mathrm{g}$ of unlabeled LDL. Specifically bound ${ }^{125} \mathrm{I}-$ LDL ( $\triangle$ ), defined as the difference in ${ }^{125}$ I-LDL bound in the presence (0) and absence (๑) of excess unlabeled LDL, was normalized to the amount of membrane protein in the sample. $D$ depicts the specific binding observed in normal subjects (๑), D.P. (O), and T.H. (৯). Values represent the mean $\pm \mathrm{SE}$ of triplicate determinations.

little as $5 \mu \mathrm{g}$ of unlabeled LDL reduced ${ }^{125} \mathrm{I}-\mathrm{LDL}$ binding by $50 \%$. In contrast, the LDL that had undergone modification of its lysyl residues by acetoacetylation did not effectively compete for the ${ }^{125} \mathrm{I}$-LDL binding site. $200 \mu \mathrm{g}$ of acetoacetylated LDL displaced $<50 \%$ of specifically bound ${ }^{125}$ I-LDL. Similarly, asialofetuin displaced little, if any, ${ }^{125} \mathrm{I}-\mathrm{LDL}$. Thus, the ${ }^{125} \mathrm{I}-\mathrm{LDL}$ was successfully displaced by unlabeled LDL but not acetoacetylated LDL or asialofetuin.

The effect of increasing concentrations of ${ }^{125} \mathrm{I}-\mathrm{LDL}$ on total, nonspecific, and specific ${ }^{125}$ I-LDL binding to normal hepatic membranes and membranes from F.H. patients was assessed at $37^{\circ} \mathrm{C}$ in the presence of calcium (Fig. 4). Although there was slightly less nonspecific ${ }^{125} \mathrm{I}-\mathrm{LDL}$ binding in T.H. and D.P. than normal, both the total and specific binding were markedly reduced. As seen in Fig. $4 \mathrm{D}$, from $8 \mu \mathrm{g}{ }^{125} \mathrm{I}$-LDL per assay on, the specific binding in both D.P. and T.H. was markedly attenuated.

Hepatic cholesterol content. The free and esterified cholesterol content from the liver of these study subjects was also determined (Table II). The total cholesterol content in liver from T.H. and 
Table II. Cholesterol and Cholesteryl Ester Content of Liver from Normal and Familial Hypercholesterolemic Subjects*

\begin{tabular}{llll}
\hline & Total & Free & Esterified \\
\hline Normal 1 & $3.23 \pm 0.09$ & $3.13 \pm 0.44$ & $0.10 \pm 0.45$ \\
Normal 2 & $3.24 \pm 0.21$ & $3.17 \pm 0.20$ & $0.07 \pm 0.29$ \\
Normal 3 & $3.39 \pm 0.13$ & $3.19 \pm 0.27$ & $0.20 \pm 0.30$ \\
Patient T.H. & $5.03 \pm 0.24$ & $3.53 \pm 0.47$ & $1.50 \pm 0.53$ \\
Patient D.P. & $7.55 \pm 0.53$ & $4.81 \pm 0.46$ & $2.74 \pm 0.70$
\end{tabular}

* Values represent the mean $\pm S E$ of triplicate samples and are expressed as nanomoles per milligram of wet tissue.

D.P. was increased by 53 and $129 \%$, respectively. The majority of this increase was found in the esterified form of cholesterol. The cholesteryl ester content was indistinguishable from zero for the three normal controls, but the levels found in D.P. and T.H. accounted for over $80 \%$ of the increase observed in total hepatic cholesterol content.

Hepatic HMG-CoA reductase activity. The HMG-CoA reductase activity from three normal livers was $8.93 \pm 1.22 \mathrm{pmol} /$ min per mg protein. Both D.P. and T.H. had comparable levels of activity at 87 and $85 \%$ of normal. Therefore, there was no difference in the activity of this enzyme between livers from normal and FH subjects.

\section{Discussion}

The liver plays a central role in mammalian lipid and lipoprotein metabolism. It is the major site for synthesis and secretion of apolipoprotein B-containing VLDL, which is the major precursor of LDL. In addition, the liver has been demonstrated to be a major site of catabolism of an injected dose of labeled LDL from the plasma of nonhuman species $(27,28)$, and hepatic recognition site for LDL has been reported in several animal studies $(9,10,12,13,21,29)$. Uptake of LDL by peripheral cells such as fibroblasts has been shown to be mediated by a well characterized, high-affinity, calcium dependent, saturable protein receptor system (30). Several lines of evidence indicate that hepatic recognition and uptake of LDL in several animal species may be more complex than has been observed for nonhepatic cell lines. First, Mahley and co-workers (29) evaluated high-affinity, calcium-dependent binding to hepatic membranes in adult mammalian species, including swine and man. No binding resembling that of the classic fibroblasts $\mathrm{LDL}$ receptor was observed. Secondly, using in vitro porcine hepatocyte cultures, Bachorick et al. (31) have shown that LDL can be bound, internalized, and degraded by uptake pathway(s) independent of pinocytosis or the classical LDL receptor pathway. These lipoprotein recognition site(s) did not resemble the classical LDL receptor. Instead, this uptake was best correlated by a lower affinity, saturable, specific binding site they had previously identified in adult porcine hepatic membranes (21). Thus, in the adult pig, specific hepatic recognition sites that differ from the characteristics of the classic fibroblasts LDL receptor appeared to be of physiologic significance. In contrast, using $\left[{ }^{14} \mathrm{C}\right]$ sucroselabeled LDL, Pittman et al. (28) demonstrated that adult porcine hepatocytes avidly bound LDL and delivered it to the lysosomes.

Our data suggest that as in swine, hepatic LDL recognition in man is unlike the classic fibroblast LDL receptor. As previously reported by Mahley and co-workers (29), little if any specific ${ }^{125} \mathrm{I}-\mathrm{LDL}$ binding was observed when low LDL concentrations and a $0-4^{\circ} \mathrm{C}$ incubation were used, the conditions classically used to determine fibroblast LDL receptors. Moreover, specific LDL binding was saturable only when the assay was performed at $37^{\circ} \mathrm{C}$ at physiological concentrations of LDL. Plasma LDL cholesterol concentrations in normal adults are $\sim 100-150 \mathrm{mg} /$ $100 \mathrm{ml}$. Since protein represents $20-25 \%$ of LDL on a weight basis (32), the normal plasma apolipoprotein-LDL concentration is $\sim 60 \mathrm{mg} / 100$ or $60 \mu \mathrm{g} / 0.1 \mathrm{ml}$. Therefore, the saturable specific binding we observed (Fig. 2) at 20-50 $\mu \mathrm{g} / 0.1 \mathrm{ml}{ }^{125} \mathrm{I}-\mathrm{LDL}$ concentration would be anticipated to be more physiologically relevant as a control mechanism than would nonsaturable binding observed at one-tenth this concentration. Furthermore, as in the swine, the specific saturable LDL binding (Fig. 3) observed at $37^{\circ} \mathrm{C}$ was only partially calcium dependent. Finally, HardersSpengel et al. (33) recently reported that adult human membranes did have a small degree of specific, saturable binding at low temperatures and LDL concentration. This binding, however, was also different from that of the classical fibroblast LDL receptor in that the binding was largely calcium independent. In addition, their reported data are at odds with the virtual absence of binding reported by Mahley and co-workers (29). Therefore, it appears that the characteristics of the hepatic recognition site for LDL in man are distinct from the characteristics of the "classic" LDL receptor of peripheral tissues, although it is specific and saturable.

By assessing the hepatic membrane recognition of LDL in two patients homozygous for receptor-negative $\mathrm{FH}$, we hoped to gain further insight into the function(s) of human hepatic membrane lipoprotein receptor function. The results obtained from the experiments depicted in Fig. 4 were intriguing. As depicted by the current concepts on lipoprotein metabolism (30), the binding of LDL to hepatic membranes from both FH homozygotes was decidedly decreased. This observation agrees with the decline in hepatic membrane binding detected in FH heterozygotes by Harders-Spengel et al. (33). But unlike the theoretic predictions, at least half of the specific LDL binding to the FH homozygote membrane remained intact.

These findings cannot be ascribed to factors such as age or prior hypolipidemic therapy. Both younger age (29) and cholestyramine treatment (34) are associated with enhanced recognition of LDL by canine hepatic membranes. Therefore, the decreased binding of LDL observed in the younger, cholestyramine-treated FH subjects in the present study appears even more striking. Since no classic fibroblast LDL receptor was present in either of these patients, this decreased binding may reflect the loss of the LDL receptor gene product as expressed in the liver. Moreover, the residual hepatic LDL binding in 
these individuals may represent hepatic receptors that are genetically distinct from the classic LDL receptor. Recognition sites for apolipoprotein E, apolipoprotein B-48, apolipoproteins A-I/A-II, or even a recognition site for some moiety other than an apolipoprotein, which to some extent interact specifically with LDL, could result in LDL residual binding observed in these studies.

The residual binding observed in the homozygote hepatic membranes of FH homozygotes is consistent with a number of observations previously made in patients with $\mathrm{FH}$ as well as in the animal model for this disease, the Watanabe Heritable Hyperlipidemic (WHHL) rabbit. Firstly, the fractional catabolic rate of an injected dose of ${ }^{125} \mathrm{I}-\mathrm{LDL}$ is reduced in FH homozygotes when compared with normals (35-38), however, the total quantity of LDL catabolized from the plasma is markedly elevated. The residual hepatic membrane binding observed in our FH homozygotes could provide for this LDL clearance in FH subjects. In addition, direct determination of LDL binding to hepatic membranes of WHHL rabbits demonstrated no classic LDL receptors (39). Despite this loss of the classic LDL receptor, $\left[{ }^{14} \mathrm{C}\right]$ sucrose-labeled LDL was bound and internalized by the liver in these animals (40). As in normal rabbits, over half an injected dose of LDL was removed by the liver in the WHHL rabbits. This uptake appears to be independent of both the classic LDL as well as pinocytotic pathways, indicating that a genetic LDL uptake pathway distinct from the classic LDL receptor exists in this animal model for FH. We cannot exclude the possibilities that either the loss of the classic LDL receptor resulted in an up-regulation of an alternate LDL binding sites or that the profoundly elevated LDL concentrations induced suppression of genetically distinct LDL binding sites. However, the physiologic implications of the residual LDL binding to FH hepatic membranes are at least as intriguing as the anticipated attenuated binding.

Finally, the observation of normal activity of the rate-limiting enzyme of cholesterol biosynthesis, HMG-CoA reductase, in FH liver indicates that despite the loss of the classic LDL receptor, a steady state is ultimately reached in the hepatocyte to normalize cholesterol biosynthesis. Effective feedback regulation of HMGCoA reductase activity in the presence of an increased hepatic free and esterified cholesterol content suggests abnormalities in hepatic cellular cholesterol and cholesteryl ester compartmentation and metabolism. The physiological effect of the loss of the classic LDL receptor and the residual LDL binding observed in these hepatic membranes on the altered hepatic cholesterolcholesteryl ester metabolism are purely speculative at the present time.

In summary, hepatic membranes of receptor-negative FH homozygotes, demonstrate decreased specific binding of LDL. The residual specific, saturable recognition receptor may reflect LDL pathways unique to mature human liver and genetically distinct from the classic LDL pathway. The observed alterations in hepatic membrane binding parallel marked changes in hepatic cholesterol and cholesteryl ester content and normal HMGCoA reductase activity. Further inquiry into the relationship between hepatic lipoprotein binding sites and hepatocyte cholesterol metabolism may shed additional insights on the regulation of hepatic lipoprotein catabolism and biosynthesis.

\section{Acknowledgments}

We would like to express our appreciation to Drs. Lee, Sangvi, and Warty at the University of Pittsburgh for the use of their facilities during a portion of these studies; to Drs. Goldstein and Brown for performing fibroblast LDL receptor studies in our FH patients; and Dr. Gilbert Ashwell for his gift of asialofetuin used in the competition studies.

\section{References}

1. Khachadurian, A. K. 1964. The inheritance of essential familial hypercholesterolemia. Am. J. Med. 37:402-407.

2. Goldstein, J. L., S. E. Dana, G. Y. Brunschede, and M. S. Brown. 1975. Genetic heterogeneity in familial hypercholesterolemia: evidence for two different mutations affecting functions of low density lipoprotein receptors. Proc. Natl. Acad. Sci. USA. 72:1092-1096.

3. Tolleshaug, H., K. K. Hobgood, M. S. Brown, and J. L. Goldstein. 1983. The LDL receptor locus in familial hypercholesterolemia. Multiple mutations disrupt transport and processing of a membrane receptor. Cell. 32:941-951.

4. Goldstein, J. L., and M. S. Brown. 1974. Binding and degradation of low density lipoproteins by cultured human fibroblasts. J. Biol. Chem. 210:5153-5162.

5. Dietschy, J. M., and J. D. Wilson. 1970. Regulation of cholesterol metabolism. New Engl. J. Med. 282:1128-1138, 1241-1249.

6. Sherrill, B. C., and J. M. Dietschy. 1976. Uptake of lipoproteins of intestinal origin in the isolated perfused liver. Circulation. 54 (Suppl. II):91.

7. Anderson, J. M., F. O. Nervi, and J. M. Dietschy. 1977. Rate constants for the uptake of cholesterol from various intestinal and serum lipoprotein functions by the liver of the rat in vivo. Biochim. Biophys. Acta. 486:298-307.

8. Stein, Y., and O. Stein. 1974. Lipoprotein synthesis, intracellular transport and secretion in liver. In Atherosclerosis. III. G. Schettler and A. Weizel, editors. Springer-Verlag, Berlin. 652-657.

9. Kovanen, P. T., M. S. Brown, and J. L. Goldstein. 1979. Increased binding of low density lipoprotein to liver membranes from rats treated with $17 \alpha$-ethinyl estradiol. J. Biol. Chem. 254:11367-11373.

10. Windler, E. E. T., P. T. Kovanen, Y. S. Chao, M. S. Brown, R. J. Havel, and J. L. Goldstein. 1980. The estradiol stimulated lipoprotein receptor of rat liver. J. Biol. Chem. 255:10464-10471.

11. Kovanen, P. T., J. L. Goldstein, D. A. Chappell, and M. S. Brown. 1980. Regulation of low density lipoprotein receptors by adrenocorticotropin in the adrenal gland of mice and rats in vivo. J. Biol. Chem. 255:5591-5598.

12. Kovanen, P. T., D. W. Bilheimer, J. L. Goldstein, J. J. Jaramillo, and M. S. Brown. 1981. Regulatory role for hepatic low density lipoprotein receptors in vivo in the dog. Proc. Natl. Acad. Sci. USA. 78:11941198

13. Kovanen, P. T., M. S. Brown, S. K. Basu, D. W. Bilheimer, and J. L. Goldstein. 1981. Saturation and suppression of hepatic lipoprotein receptors: a mechanism for the hypercholesterolemia of cholesterol-fed rabbits. Proc. Natl. Acad. Sci. USA. 78:1396-1400.

14. Havel, R. J., H. A. Eder, and J. H. Bragdon. 1955. The distribution and chemical composition of ultracentrifugally separated lipoproteins in human serum. J. Clin. Invest. 34:1345-1353. 
15. Redding, C. M., and D. Steinberg. 1960. Studies on the synthesis and secretion of serum lipoproteins by rat liver slices. J. Clin. Invest. 39:1560-1569.

16. MacFarlane, A. S. 1958. Efficient trace labeling of proteins with iodine. Nature (Lond.). 182:53.

17. Bilheimer, D. W., S. Eisenberg, and R. I. Levy. 1972. The metabolism of very low density lipoproteins. I. Preliminary in vitro and in vivo observations. Biochim. Biophys. Acta. 260:212-221.

18. Lowry, O. H., N. J. Rosebrough, A. L. Farr, and R. J. Randall. 1951. Protein measurement with the Folin phenol reagent. J. Biol. Chem. 193:265-275.

19. Mahley, R. W., T. L. Innerarity, K. H. Weisgraber, and S. Y. Oh. 1979. Altered metabolism (in vivo and in vitro) of plasma lipoproteins after selective chemical modification of lysine residues of the apoproteins. J. Clin. Invest. 64:743-750.

20. Basu, S. K., J. L. Goldstein, and M. S. Brown. 1978. Characterization of low density lipoprotein receptor in membranes prepared from human fibroblasts. J. Biol. Chem. 253:3852-3856.

21. Bachorick, P. S., P. O. Kwiterovich, and J. C. Cook. 1978. Isolation of a procine liver plasma membrane fraction that binds low density lipoproteins. Biochemistry. 17:5287-5299.

22. Beg, Z. H., J. A. Stonik, and H. B. Brewer, Jr. 1978. 3-hydroxy3-methylglutaryl coenzyme A reductase: regulation of enzymatic activity by phosphorylation and dephosphorylation. Proc. Natl. Acad. Sci. USA. 75:3678-3682.

23. Lipid research clinical program manual of laboratory operations. 1974. U. S. Department of Health, Education and Welfare. DHEW Report Number (NIH) 75-628.

24. Burstein, M., and J. Samaille. 1960. Sur in dosage rapide du cholesterol liet aux $\beta$-lipoproteinemia du serum. Clin. Chim. Acta. 5:609613.

25. Heider, J. G., and Boyette, R. L. 1978. The picomole determination of free and total cholesterol in cells in culture. J. Lipid Res. 19:514-518.

26. Beisiegel, V., W. J. Schneider, J. L. Goldstein, R. G. W. Anderson, and M. S. Brown. 1981. Monoclonal antibodies to the low density lipoprotein receptor as probes for study of receptor-mediated endocytosis and the genetics of familial hypercholesterolemia. J. Biol. Chem. 256:11923-11931.

27. Hay, R. V., L. A. Pottenger, A. L. Reingold, and G. S. Getz. 1971. Degradation of ${ }^{125}$ I-labeled serum low density lipoprotein in normal and estrogen-treated male rats. Biochem. Biophys. Res. Commun. 44:1471-1477.

28. Pittman, R. C., A. D. Attie, T. E. Carew, and D. Steinberg. 1979. Tissue sites of degradation of low density lipoprotein: application of a method for determining the fate of plasma proteins. Proc. Natl. Acad. Sci. USA. 76:5345-5349.
29. Mahley, R. W., D. Y. Hui, T. L. Innerarity, and K. H. Weisgraber. 1981. Two independent lipoprotein receptors in hepatic membranes of dog, swine, and man. J. Clin. Invest. 68:1197-1206.

30. Brown, M. S., P. T. Kovanen, and J. L. Goldstein. 1981. Regulation of plasma cholesterol by lipoprotein receptors. Science (Wash. DC). 212:628-635.

31. Bachorick, P. S., F. A. Franklin, D. G. Virgil, and P. O. Kwiterovich, Jr. 1982. High affinity uptake and degradation of apolipoprotein E free high-density lipoprotein in cultured porcine hepatocytes. Biochemistry. 21:5675-5684.

32. Osborne, J. C., and H. B. Brewer, Jr. 1977. The plasma lipoproteins. Adv. Protein Chem. 31:253-337.

33. Harders-Spengel, K., C. B. Wood, G. R. Thompson, N. B. Myant, and A. K. Soutar. 1982. Difference in saturable binding of low density lipoprotein to liver membranes from normocholesterolemic subjects and patients with heterozygous familial hypercholesterolemia. Proc. Natl. Acad. Sci. USA. 79:6355-6359.

34. Angelin, B., C. A. Raviola, T. L. Innerarity, and R. W. Mahley. 1983. Regulation of hepatic lipoprotein receptors in the dog. Rapid regulation of apolipoprotein B, E receptors, but not of apolipoprotein $\mathrm{E}$ receptors, by intestinal lipoproteins and bile acids. J. Clin. Invest. 71:816-831.

35. Reichl, D. L., L. A. Simons, and N. B. Myant. 1974. The metabolism of low density lipoprotein in a patient with familial hyperbetalipoproteinemia. Clin. Sci. Mol. Med. 47:635-638.

36. Simons, L. A. D., D. Reichl, N. B. Myant, and M. Mancini. 1975. The metabolism of the apoprotein of plasma low density lipoprotein in familial hyperbetalipoproteinemia in the homozygous form. Atherosclerosis. 21:283-298.

37. Bilheimer, D. W., J. L. Goldstein, S. M. Grundy, and M. S. Brown. 1975. Reduction in cholesterol and low density lipoprotein synthesis after portacaval shunt surgery in a patient with homozygous familial hypercholesterolemia. J. Clin. Invest. 56:1420-1430.

38. Thompson, G. R., A. K. Soutar, F. A. Spengel, A. Jadhav, S. J. P. Gavigan, and N. B. Myant. 1981. Defects of receptor-mediated low density lipoprotein catabolism in homozygous familial hypercholesterolemia and hypothyroidism in vivo. Proc. Natl. Acad. Sci. USA. 78:2591-2595.

39. Kita, T., M. S. Brown, Y. Watanabe, and J. L. Goldstein. 1981. Deficiency of low density lipoprotein receptors in liver and adrenal gland of the WHHL rabbit, an animal model of familial hypercholesterolemia. Proc. Natl. Acad. Sci. USA. 78:2268-2272.

40. Pittman, R. C., T. E. Carew, A. D. Attie, J. L. Witztum, Y. Watanabe, and D. Steinberg. 1982. Receptor-dependent and receptorindependent degradation of low density lipoproteins in normal rabbits and receptor-deficient mutant rabbits. J. Biol. Chem. 257:7997-8000. 